\title{
A lack of Wolbachia-specific DNA in samples from apollo butterfly (Parnassius apollo, Lepidoptera: Papilionidae) individuals with deformed or reduced wings
}

\author{
Kinga Lukasiewicz $^{1,2} \cdot$ Marek Sanak $^{1} \cdot$ Grzegorz Węgrzyn $^{2}$
}

Received: 10 August 2015 /Revised: 9 September 2015 / Accepted: 14 September 2015 /Published online: 30 September 2015

(C) The Author(s) 2015. This article is published with open access at Springerlink.com

\begin{abstract}
Various insects contain maternally inherited endosymbiotic bacteria which can cause reproductive alterations, modulation of some physiological responses (like immunity, heat shock response, and oxidative stress response), and resistance to viral infections. In butterflies, Wolbachia sp. is the most frequent endosymbiont from this group, occurring in about $30 \%$ of species tested to date. In this report, the presence of Wolbachia-specific DNA has been detected in apollo butterfly (Parnassius apollo). In the isolated population of this insect occurring in Pieniny National Park (Poland), malformed individuals with deformed or reduced wings appear with an exceptionally high frequency. Interestingly, while total DNA isolated from most (about $85 \%$ ) normal insects contained Wolbachia-specific sequences detected by PCR, such sequences were absent in a large fraction (70 \%) of individuals with deformed wings and in all tested individuals with reduced wings. These results indicate for the first time the correlation between malformation of wings and the absence of Wolbachia sp. in insects. Although the lack of the endosymbiotic bacteria cannot be considered as the sole cause of the deformation or reduction of wings, one might suggest that Wolbachia sp. could play a protective role in the ontogenetic development of apollo butterfly.
\end{abstract}

Communicated by: Agnieszka Szalewska-Palasz

Grzegorz Wegrzyn

grzegorz.wegrzyn@biol.ug.edu.pl

1 Division of Molecular Biology and Clinical Genetics, Department of Medicine, Jagiellonian University Medical College, Skawińska 8, 31-066 Cracow, Poland

2 Department of Molecular Biology, University of Gdańsk, Wita Stwosza 59, 80-308 Gdańsk, Poland
Keywords Wolbachia · Apollo butterfly · Deformed wings · Reduced wings

\section{Introduction}

The genus Wolbachia groups as a maternally inherited endosymbiotic $\alpha$-proteobacteria. They live inside of cells of arthropods and filarial nematodes (Serbus et al. 2008). In insects, Wolbachia sp. can cause reproductive alterations, like feminization, parthenogenesis, male killing, and cytoplasmic incompatibility (Salunkhe et al. 2014). However these bacteria may also provide particular ecological benefits to the host (Saridaki and Bourtzis 2010). These mutualistic Wolbachia-host interactions include gene expression-dependent modulation of host immunity, heat shock response, and oxidative stress response, prevention of nurse cells apoptosis, and resultant effective maturation of oocytes, as well as host resistance to various viral infections (reviewed by Saridaki and Bourtzis 2010). Intriguingly, some effects of Wolbachia sp. on their hosts depend on the bacterial strain and the insect species (discussed by Iturbe-Ormaetxe and O'Neill 2007).

In butterflies (Lepidoptera), it was reported that about $30 \%$ of species are infected with Wolbachia sp. (Russell et al. 2012). Interestingly, Wolbachia sp. is a highly predominant, heritable symbiont in these insects, as the presence of other such microorganisms (Arsenophonus spp., Cardinium hertigii, Hamiltonella defensa, and Spiroplasma spp.) was very rare in all tested families but Riodinidae (Russell et al. 2012). In Papilionidae, Wolbachia sp. was the only detected endosymbiont, and occurred in $20 \%$ of tested species (Russell et al. 2012).

Apollo butterfly (Parnassius apollo) is a representative of Papilionidae. This butterfly was quite common in Europe in the nineteenth century. However, its distribution and 
Fig. 1 Examples of $P$. apollo individuals with normal (panel a), deformed (panel b), or reduced (panel c) wings. Photographs were made by the authors

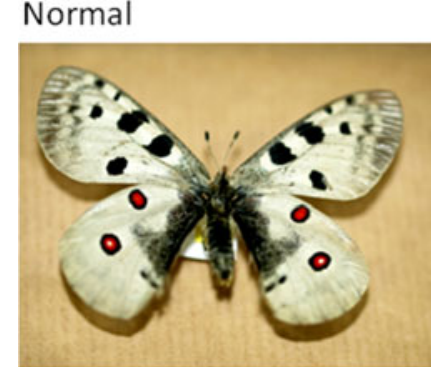

a

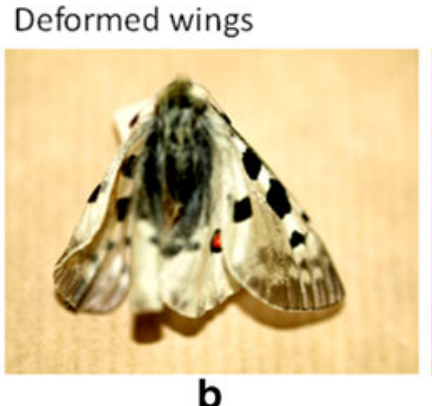

b

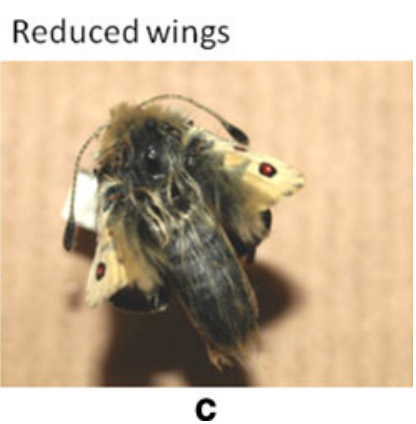

population size have declined severely during the twentieth century, thus, it is near threatened now (Nakonieczny et al. 2007; van Swaay et al. 2010; Łozowski et al 2014). In this light, it is not a surprise that various programs focused on protection and survival of $P$. apollo have been established. They are, however, challenging as the remaining populations are sometimes extremely small. This was the case in the Pieniny National Park (Poland), where the apollo butterfly population had declined to about 20-30 individuals in the early 1990s (Witkowski and Adamski 1996; Witkowski et al. 1997). The restitution of this population has been successful, but since the late 1990s often appearance of insects with deformed or severely reduced wings has been noted (Adamski and Witkowski 1999). The mechanisms of these malformations remain to be elucidated. In this work, in order to determine if the presence of Wolbachia sp. might influence insect wing development, by using the applied genetics approach, we tested the presence of Wolbachia-specific DNA in samples derived from normal and malformed apollo butterflies.

\section{Materials and methods}

\section{Insects}

All insects used in this work were from the collection of the Pieniny National Park (specimens were collected in years
1991-2007). The permission for the use of this material has been obtained from the Director of the Pieniny Natonal Park (permission no. PB-5232-24/07, topic ID: p0748). For experiments, five individuals of Pieris rapae (used as a positive control, reported previously to contain Wolbachia sp.; Tagami and Miura 2004), and 52 individuals of P. apollo were employed. Among the $P$. apollo specimens, 22 had normal wings, ten had deformed wings, and 20 had reduced wings. Photographs of examples of individuals from each group are shown in Fig. 1.

\section{DNA isolation and amplification}

Total DNA was isolated from a material withdrawn from legs of investigated insects. The Sherlock AX Purification Kit (A\&A Biotechnology, Gdynia, Poland) was used according to the manufacturer's instruction.

DNA fragments, corresponding to particular tested genes, were amplified by PCR with the use of primers which are listed in Table 1. Amplified DNA was separated by agarose gel electrophoresis and analyzed according to Sambrook and Russell (2001).

\section{Results and discussion}

To analyze the presence of Wolbachia-specific DNA in $P$. apollo individuals, total DNA was isolated from samples

Table 1 Primers used in PCR

\begin{tabular}{lll}
\hline Gene & Primers (forward and reverse) & Reference \\
\hline$d p p$ & 5' AGA GAA CGT GGC GAG ACA CTG & Kapan et al. (2006) \\
& 5' GAG GAA AGT TGC GTA GGA ACG & \\
$h h$ & 5' AAG GAA AAA CTG AAT ACG CTG GC & Kapan et al. (2006) \\
& 5' CGA GAC GCC CCA ACT TTC C & \\
ptc & 5' CTC CGA AGA AGG TCT GCC GCA AG & Kapan et al. (2006) \\
& 5' AAT TCG TGC TCG TCG TAT TTT C & \\
16S rRNA & 5' GGA ACA CCA GTG GCG AAG GCG TCT & $\begin{array}{c}\text { This work, designed on the basis of the 16S } \\
\text { rRNA gene of Wolbachia sp., using the }\end{array}$ \\
& 5' CTG TGT GAA ACC CGG ACG AAC C & $\begin{array}{l}\text { OLIGO 6.7 software (Molecular Biology } \\
\text { Insights Inc., Colorado Springs, CO) }\end{array}$ \\
\hline
\end{tabular}


Table 2 Results of PCRmediated DNA amplification with the use of indicated templates and primers specific to the 16S rRNA gene of Wolbachia sp

\begin{tabular}{llll}
\hline Species and characteristics & \multicolumn{2}{l}{ Number of individuals used for DNA isolation } \\
\cline { 2 - 4 } & All tested & $\begin{array}{l}\text { With Wolbachia } \\
\text { specific PCR product }\end{array}$ & $\begin{array}{l}\text { Without Wolbachia } \\
\text { specific PCR product }\end{array}$ \\
\hline P. rapae (normal) & 5 & 5 & 0 \\
P. apollo (normal) & 22 & 19 & 3 \\
P. apollo (with deformed wings) & 10 & 3 & 7 \\
P. apollo (with reduced wings) & 20 & 0 & 20 \\
\hline
\end{tabular}

of legs of either normal (20 butterflies) or malformed (32 butterflies) insects. In addition, for external positive control, DNA was isolated analogously from wild-type Pieris rapae (five butterflies), as the presence of Wolbachia sp. in this species has already been reported (Tagami and Miura 2004).

The quality of DNA templates were proved by PCR reactions with primers for amplification of fragments of $d p p, h h$, and ptc genes, present in the insect genome (Table 1). The product of amplification of the fragment of the 16S RNA gene of Wolbachia sp., obtained with the specific primers and using DNA isolated from wild-type $P$. rapae, was 336 bp long, as expected from the Wolbachia sp. genome analysis.

When the presence of the Wolbachia-specific DNA fragment after PCR with templates derived from $P$. apollo samples was tested, the $336 \mathrm{bp}$ amplification product has been detected in the reaction containing the material from 19 out of 22 normal butterflies (Table 2). However, such a specific signal could be observed in only three out of ten individuals with deformed wings. Moreover, none of the 20 butterflies with reduced wings revealed the presence of Wolbachia sp. in this test (Table 2).

The results presented in Table 2 confirmed that $P$. rapae cells contain Wolbachia sp., and indicated that this endosymbiont is also present in $P$. apollo. Nevertheless, the most intriguing result is the strong correlation between wing malformations (deformation and reduction) and the absence of Wolbachia sp. To our knowledge, this is the first indication that this maternally inherited endosymbiotic bacterium might be important for proper development of wings in insects. Since Wolbachia sp. was found in only $20 \%$ of tested species from Papilionacae, and it was absent in some normal individuals of $P$. apollo, while present in some butterflies with deformed wings (Table 2), a possibility that the lack of this bacterium might determine wing malformation is unlikely. Nevertheless, the strong association of the absence of Wolbachia sp. with deformation and reduction of wings in apollo butterflies may suggest that this endosymbiont could protect its host from some deleterious factors or agents affecting insect development.

In summary, this is the first report showing a correlation between wing malformation and the absence of Wolbachia sp. in $P$. apollo. Although the mechanism of this phenomenon remains to be elucidated, we speculate that Wolbachia sp. might play a protective role in the ontogenetic development of this insect. Therefore, the potential application of the results presented in this report is a possibility of the selection of Wolbachia-positive individuals (based on genetic tests) of $P$. apollo for further works on regeneration of populations of this butterfly, and its protection.

Acknowledgments This work was supported by Ministry of Science and Higher Education (Poland) (project grant no. N N304 339633 to Kinga Lukasiewicz) and the University of Gdańsk (task grant no. 530L140-D242-15-1A).

Conflict of interest The authors declare that they have no conflict of interest.

Open Access This article is distributed under the terms of the Creative Commons Attribution 4.0 International License (http:// creativecommons.org/licenses/by/4.0/), which permits unrestricted use, distribution, and reproduction in any medium, provided you give appropriate credit to the original author(s) and the source, provide a link to the Creative Commons license, and indicate if changes were made.

\section{References}

Adamski P, Witkowski Z (1999) Wing deformation in an isolated Carpathian population of Parnassius apollo (Papilionidae: Parnassinae). Nota Lepid 22:67-73

Iturbe-Ormaetxe I, O'Neill SL (2007) Wolbachia-host interactions: connecting phenotype to genotype. Curr Opin Microbiol 10:221224

Kapan DD, Flanagan NS, Tobler A, Papa R, Reed RD, Gonzalez JA, Restrepo MR, Martinez L, Maldonado K, Ritschoff C, Heckel DG, McMillan WO (2006) Localization of Müllerian mimicry genes on a dense linkage map of Heliconius erato. Genetics 173:735-757

Łozowski B, Kędziorski A, Nakonieczny M, Łaszczyca P (2014) Parnassius apollo last-instar larvae development prediction by analysis of weather condition as a tool in the species' conservation. C R Biol 337:325-331

Nakonieczny M, Kędziorski A, Michalczyk K (2007) Apollo butterfly (Parnassius apollo L.) in Europe - its history, decline and perspectives of conservation. Funct Ecosyst Commun 1:56-79

Russell JA, Funaro CF, Giraldo YM, Goldman-Huertas B, Suh D, Kronauer DJ, Moreau CS, Pierce NE (2012) A veritable menagerie of heritable bacteria from ants, butterflies, and beyond: broad molecular surveys and a systematic review. PLoS One 7:e51027 
Salunkhe RC, Narkhede KP, Shouche YS (2014) Distribution and evolutionary impact of wolbachia on butterfly hosts. Indian J Microbiol $54: 249-254$

Sambrook J, Russell DW (2001) Molecular cloning: a laboratory manual, 3rd edn. Cold Spring Harbor Laboratory Press, Cold Spring Harbor, NY

Saridaki A, Bourtzis K (2010) Wolbachia: more than just a bug in insects genitals. Curr Opin Microbiol 13:67-72

Serbus LR, Casper-Lindley C, Landmann F, Sullivan W (2008) The genetics and cell biology of Wolbachia-host interactions. Annu Rev Genet 42:683-707

Tagami Y, Miura K (2004) Distribution and prevalence of Wolbachia in Japanese populations of Lepidoptera. Insect Mol Biol 13:359-364 van Swaay C, Wynhoff I, Verovnik R, Wiemers M, López Munguira M, Maes D, Sasic M, Verstrael T, Warren M and Settele J (2010) Parnassius apollo. The IUCN Red List of Threatened Species. Version 2015.2. <www.iucnredlist.org>. Downloaded on 3 August 2015

Witkowski Z, Adamski P (1996) Decline and rehabilitation of the Apollo butterfly Parnassius apollo (Linnaeus, 1758) in the Pieniny National Park (Polish Carpathians). In: Settele J, Margules CR, Poschlod P, Henle K (eds) Species Survival in Fragmented Landscapes. Kluwer Academic Publishers, Dordrecht, pp 7-14

Witkowski Z, Adamski P, Kosior A, Płonka P (1997) Extinction and reintroduction of Parnassius apollo in the Pieniny National Park (Polish Carpathians). Biologia 52:199-208 